MARIAN KISIEL

\title{
POEMAT O ŚMIERCI. ROZWAŻANIE O ŚMIERCI KAROLA WOJTYŁY JAKO MEDYTACJA FILOZOFICZNO-RELIGIJNA
}

1. Rozważanie o śmierci to ostatni przed intronizacją poemat Karola Wojtyły (zob. Gruda, przedruk: Wojtyła, Dzieła literackie) ${ }^{1}$. Opublikowany w roku 1975 , sygnowany jak zwykle pseudonimem, podobnie jak wcześniejsze utwory literackie kapłana, został pominięty w refleksji krytycznej. Ta wieloczęściowa, pisana zmienną miarą wierszową, gatunkowo nieokreślona, w jakimś sensie meandryczna stylistycznie wypowiedź poetycka, została zauważona przez krytyków i badaczy dopiero po „dekonspiracji” papieskiej (Okoń 87). Opinię Zofii Zarębianki, że jest to ,jeden z najbardziej wymagających intelektualnie i trudnych do interpretacji utworów" (Zarębianka 139), cytuję tutaj nie dla jej oczywistej pewności, ale dla podkreślenia okazjonalności, z jaką dochodzą do niego czytelnicy-znawcy. Skala trudności Rozważania o śmierci obrazuje pośrednio, dlaczego interpretacji poematu nie mamy, natomiast to, co napisano na jego temat, jest ekspozycją nie literackiej tkanki, lecz myśli teologiczno-filozoficznej, jaka została w nim zawarta. Nie odbierając prawa do takich prób lektury, przeczytajmy jednak poemat Wojtyły tak, jak czyta się wiersz, nie rezygnując - rzecz jasna - z wartości w nim naddanych.

2. Rozważanie o śmierci jest poematem filozoficzno-religijnym (Błoński 149), a ściślej - medytacją, która przybrała kształt poematu. Rozpoczyna się cyklem Myśli o dojrzewaniu. „Myśli” kierują nas w stronę dociekań spekulatywnych, „dojrzewa-

Prof. dr hab. MARIAn KISIEL - Instytut Literaturoznawstwa UŚ w Katowicach; adres do korespondencji: Wydział Humanistyczny Uniwersytetu Śląskiego, pl. Sejmu Śląskiego 1, 40-032 Katowice; e-mail: marian.kisiel@us.edu.pl. ORCID: http://orcid.org/0000-0002-6752-2407.

${ }^{1}$ Przedruk: Wojtyła, Dzieła literackie i teatralne, 2020. Z tego wydania cytaty bezpośrednio w tekście głównym oznaczam tom cyfrą rzymską, strony zaś arabską. 
nie” odczytujemy jako zwrot „ku” czemuś, co swojej ostatecznej formy jeszcze nie przybrało. Tytułowe „dojrzewanie” jest procesem i pozornie kłóci się z tym, o czym poeta będzie pisał w trzech następujących po sobie sekwencjach. Nie pojawi się w nich „dojrzewanie” ale „dojrzałość”. Jeżeli więc „dojrzewanie” jest „myślą”, to ku czemu prowadzi? Kategoria aspektu - dokonane, niedokonane - otwiera nas na naszą „dziejowość”, albowiem - przypomnijmy za Heideggerem - od kiedy jesteśmy ,jedna rozmową”, jesteśmy „dziejowi” (Heidegger 191).

Dojrzewanie „ku” śmierci (czyli - proces) jest najpierw zastanowieniem nad „dojrzałością” (czyli - stanem). „Dojrzałość” - powiada poeta - to „zstępowanie”, „przybliżenie powierzchni do dna”, ,przenikanie głębi”, a także gotowość „do trudnych spotkań”. To także ,pełnia” i ,jesień” (II 159). Nie znajdziemy w tych słowach skoncentrowania się na konkrecie, desygnat jest niejasny lub niemożliwy do wskazania, albowiem między tym, kto mówi, a tym, kto słucha, (z)rozumienie znaczeń słów jest utrudnione $\mathrm{z}$ uwagi na ich przeniesienie do kręgu pojęć abstrakcyjnych. I jakkolwiek z owego kręgu wysuwa się człowiek postrzegający siebie dualistycznie jako „ciało” i „dusza”, to jednak nie jest on ujmowany w swojej fizyczności, czy cielesności, lecz - duchowości. Mówiąc inaczej, konkretny człowiek zostaje zastąpiony formułą nieoznaczoną, myślaną.

W pierwszej sekwencji Myśli o dojrzewaniu „myślenie” zostanie pokazane jako otwarcie drogi ,ku”:

Dojrzałość, zstępowanie do ukrytego rdzenia,

opadają warstwy wyobraźni jakby liście zawarte w pniu,

wyciszają się takie komórki, którymi wrażliwość jeszcze się nie rozbudza,

a ciało własną swoją pełnią dosięga brzegów jesieni -

dojrzałość, przybliżenie powierzchni do dna,

dojrzałość przenikanie głębi,

dusza bardziej pojednana $\mathrm{z}$ ciałem,

bardziej śmierci przeciwna,

niespokojna o zmartwychwstanie.

Dojrzałość do trudnych spotkań.

Poeta nie chce być liryczny czy poetycko wyrafinowany. Nie dba o wersyfikację, która - formalnie przynajmniej - zbliżałaby jego wypowiedź do klasycznej formuły wierszowej, gdzie ekwiwalencja wersów wpływa jednocześnie na organizację semantyczną utworu. Wersyfikacja została tutaj podporządkowana logice następstw, ma charakter „myślowy”, a w „punktowym” wyliczaniu, czym jest „dojrzałość”, chodzi raczej o pozbawione wątpliwości dojście do intelektualnej pointy, która będzie definiowała bohatera Rozważania o śmierci. Taki rodzaj wypowiedzi kieruje nas w stronę narracyjnej poezji klasycystycznej, bardziej otwartej na formuły 
traktatowe niż poezja nowoczesna, gdzie pewność konstatacji ulega zawieszeniu na rzecz wątpliwych przeświadczeń.

Bohatera Rozważania o śmierci trudno, a nawet nie można nazwać lirycznym. Nie można także - za Sørenem Kierkegaardem - nazwać go tragicznym bądź estetycznym, ponieważ pierwszy jest „czystym człowiekiem”, „ulubieńcem etyki”, „wszystko, co czyni, czyni otwarcie”, drugi natomiast ,jest bohaterem milczącym”, „może mówić, ale nie chce” (Kierkegaard 125). Wojtyła usuwa tutaj tę dialektykę mowy i milczenia. Kieruje nas w stronę świadomości, sytuując człowieka na płaszczyźnie dociekań, poza jego emocjami. I nawet wtedy, kiedy mówi, że „ciało własną swoją pełnią dosięga brzegów jesieni” (II 159), to - przypomnijmy Jana Błońskiego - „słowo jest w tych poematach zawsze czyimś” (Błoński 148), czyli aktualizuje myśli już wcześniej poznane, na nowo jednak włączone do powszechnego użytku.

Sekwencja pierwsza Myśli o dojrzewaniu nie jest samoistna. Przypominając o duchowo-cielesnej formie człowieka, zmierza ku konstatacji ogólnej, iż kres zawsze jest „trudnym spotkaniem” i to spotkanie jest mierzone „dojrzałością”. W sekwencji drugiej duchowo-cielesna forma człowieka znika, mowa będzie o „dojrzałości” jako „bojaźni”, która jest zarówno „początkiem mądrości” i zaprzeczeniem „ucieczki” („nie jest już potrzebą ucieczki”), jak też miarą „wielkości”. Zauważmy: o ile wcześniej podmiot mówiący dawał bezosobowo atrybutywną lekcję „dojrzałości” (czym ona jest), to teraz pojawia się w wypowiedzi poety formuła samozwrotna „my”. W przestrzeń tekstową zostają włączeni ten, który mówi, i ci, do których mówi. Wspólnota losu nie jest jednakże wynikiem wzajemnego związania „ciał” $\mathrm{i}$,dusz”. W tej sekwencji poematu realnie ich nie ma, ponieważ zostały zastąpione przypowieścią o mądrości obumierającego ziarna (J 12,24), i o tym, że „Kres uprawy zawiera się już w jej początku" (II 159). Zamiast dualistycznie postrzegającej siebie istoty, mamy jej alegoryczny ekwiwalent, wyrażony w słowie cudzym:

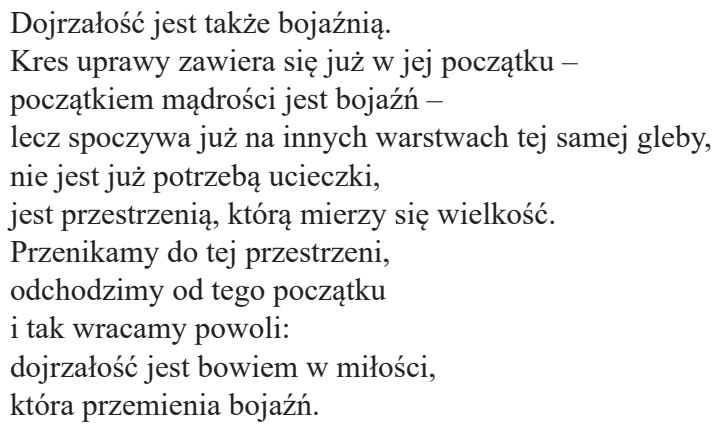

W tej sekwencji cyklu dochodzi do głosu teolog. Poeta myśli jest liryczny w stopniu większym niż w sekwencji poprzedniej. Tam wypowiadał się traktatowo, tutaj 
teologicznie. Już nie wystarcza ewangeliczna alegoreza, trzeba wypowiedź spersonalizować. Jan Okoń pisał: „Wszystko po to, ażeby - jak w homilii - nie poprzestać na samym obrazie i żeby do wewnętrznej akcji włączyć także odbiorcę" (Okoń 103). Jeśli bowiem sekwencja pierwsza Myśli o dojrzewaniu była przygotowaniem do „trudnych spotkan”, ,wyciszeniem komórek” i „przybliżeniem powierzchni do dna", to w sekwencji drugiej mowa jest o wspólnej (stąd forma 1 os. liczby mnogiej) dojrzałości, która jest otwarciem na „bojaźń”, lecz nie na lęk. Na „miłość”, a nie na rozpacz; na „mądrość”, a nie na „zabłąkanie”, o którym Kierkegaard pisał, że „pogarsza stan błądzenia” (Kierkegaard 183). „Bojaźń”, będąca „miarą wielkości”, jest usunięciem lęku; ,dojrzałość jest bowiem w miłości / która przemienia bojaźń" (II 160). Ks. Helmut Juros omawiając aspekt teologiczno-moralny pojęcia, skonstatował: „Porzucenie b.[ojaźni] jest obowiązkiem tych, którzy »są z ducha« (Rz 8,15), uzasadnionym ostatecznie przez miłość (1 J 4,18; por. pol. przysłowie »Miłość z bojaźnią nie stoi, nie miłuje, kto się boi«)" (Juros kol. 740).

Interpretacja „bojaźni” w sekwencji trzeciej Myśli o dojrzewaniu jest summa, a może tylko wynikiem prawd, jakie zostały zawarte wcześniej. Określmy znamienną regułę poetyki Wojtyły, nazwijmy ją ,wynikaniem”: Autor zakreśla najpierw pole znaczeniowe pojęcia „dojrzałość” (sekwencja pierwsza), następnie wyprowadza z niego pojęcia „bojaźni” i „miłości” (sekwencja druga), by wokół nich zbudować ostateczny szkielet wiary, którą Kierkegaard w Bojaźni i drżeniu nazywa - jak pamiętamy - „namiętnością”, a Wojtyła w Myślach o dojrzewaniu - „pragnieniem”. Kierkegaard pisał: „Najwyższą namiętnością człowieka jest wiara i żadne pokolenie nie zaczyna wierzyć od innego punktu niż pokolenia poprzednie, każde pokolenie zaczyna od początku, następne pokolenie nie posuwa się dalej w tym względzie od poprzedniego, jeżeli to ostatnie było wierne swojemu zadaniu i nie odrzuciło go" (Kierkegaard 135). Wojtyła podobne przekonanie „przerabia” na własny rachunek, odwołując się do ksiąg sapiencjalnych Starego Testamentu, zwłaszcza do Księgi Przysłów i Księgi Psalmów. Ks. Lech Stachowiak przypomina: „Często wezwanie do b.[ojaźni] B.[ożej] służy w Prz [Księdze Przysłów] do podkreślenia rel.[igijnego] charakteru czysto mądrościowych relacji: jest ona "początkiem mądrości« (Ps 111,10; Prz 9,10)) lub »początkiem poznania« (Prz 1,7)" (Stachowiak kol. 741).

W sekwencji trzeciej Myśli o dojrzewaniu „bojaźń i miłość wybuchną przeciwnym sobie pragnieniem" (II 160):

Gdy znajdziemy się u brzegów jesieni,

bojaźń i miłość wybuchną przeciwnym sobie pragnieniem,

bojaźń pragnieniem powrotu do tego, co już było istnieniem

i wciąż jeszcze nim nie jest -

miłość pragnieniem odejścia ku Temu, w Kim istnienie znajduje całą swą przyszłość.

W nas, patrzących ku brzegom jesieni, 
zmaganie przebiega wzdłuż tego podziału,

jaki każdy człowiek w sobie nosi,

gdy ciało wciąż w nim stanowi przeszłość jego własnej przyszłości,

- każdy, gdy swej własnej przyszłości nie potrafi łączyć ze swym ciałem...

Tak schodzą się w jedno - niczym promienie w soczewce - myśli o „brzegach jesieni”, które są „podziałem” zarówno egzystencjalnym (na „ciało” i „duszę”), jak i transcendentalnym (na „powrót” i „odejście”). Poeta eksponując przyimek „ku” - znak drogi i miejsce w przestrzeni - zaznacza, że „wzdłuż tego podziału” droga biegnie „ku Temu, w Kim istnienie znajduje całą swą przyszłość” (II 160). W ten sposób Wojtyła otwiera nas także na kolejną część poematu odnoszącą się do Tajemnicy Przejścia.

3. Poezja ustępuje w niej miejsca traktatowi. Mysterium paschale w stopniu większym niż Myśli o dojrzewaniu ma budowę zmąconą, jest cyklem sekwencji niejednorodnych, mieszaniną niemogących się wzajemnie dookreślić fragmentów. A jednak - paradoksalnie - właśnie tutaj ujawnia się jakaś podskórna uczuciowość, która osłabia dogmatyczność czy też arbitralność teologicznej prawdy. W wersie otwierającym sekwencje pierwszą i trzecią: „Nurtów mijania nie zatrzymasz. Jest ich wiele" (II 160, 161), adresatywność jest wielce wymowna. Ferdinand Ebner pisał: „Ty jest daną drugiemu człowiekowi «możliwością bycia zagadniętym»” (Ebner 32), co znaczy, że w „możliwości bycia zagadniętym” zawiera się - wyprowadzona przez Heideggera z Hölderlina - pewność, że ,jesteśmy jedna rozmowa” i „,możemy słyszeć się nawzajem” (Heidegger 191). Zwracając się do kogoś zaimkowo przez Ty, ustalamy relację bliskości. Jest to - zauważa Ebner - relacja do Boga, albowiem „istnieje tylko jedno Ty, którym jest Bóg” (Ebner 37-38). „W moim [zaś] rzeczywiście duchowym stosunku do innych ludzi Ty [...] jest [...] zawsze jednym i tym samym Ty, jedynym, jakie istnieje" (Ebner 38). Tak samo twierdził Kierkegaard, pisząc o „obowiązku względem Boga”: „spełniając ten obowiązek nie wchodzę w stosunek z Bogiem, lecz z bliźnim” (Kierkegaard 72):

Nurtów mijania nie zatrzymasz. Jest ich wiele,

biegną wokół, tworzą pole, w którym przemijasz sam,

pogodzony, bo jednak coś wzbiera,

bo rośnie wokoło świat.

I we mnie

coś zostaje z dziedzictwa i coś z zapowiedzi:

nurt mijania jest też nurtem wzbierania.

Tych nurtów nie wytrzymasz do końca,

pójdą dalej - sam opadniesz poniżej, to wiesz

na pewno

i w proch się obrócisz, to wiesz

na pewno - 
istniejesz stale ku śmierci, istniejąc wciąż ku przyszłości, ona stale wstępuje w twój nurt.

Czy wyzwoli cię z pól przemijania?

czy odbierze istnieniu całą przeszłość i przyszłość zarazem?

Zwrot do bliźniego ujęty jest tu w dobre słowo, wypowiedziany z uczuciem, w którym nie ma groźby. Kiedy poeta przypomina (to chyba dobre określenie) o nieuchronnym końcu człowieka, w jego słowach można usłyszeć nie tyle wanitatywne myśli Koheleta, ile przeświadczenie Heideggera, że bycie Ty (Dasein) jest byciem ku śmierci (Sein zum Tode): „nurtów mijania nie zatrzymasz”; ,przemijasz sam”; „tych nurtów nie wytrzymasz do końca”; „sam opadniesz poniżej”; „,w proch się obrócisz, to wiesz / na pewno"; ,istniejesz stale ku śmierci, istniejąc wciąż ku przyszłości" (II 160, 161). A jednak Angst (trwoga) nie jest drogą „ku” Verfallen (upadaniu). Kiedy w Myślach o dojrzewaniu mowa była o „dojrzałości” jako „bojaźni”, poeta przypominał, że jest ona „początkiem mądrości” i „nie jest już potrzebą ucieczki” (II 159). W połączeniu Ty z Ja lęk przed kresem ulega nie tyle osłabieniu, ile przemienia się we wspólne doświadczenie tego, który mówi i tego, do kogo się mówi. Ponieważ ,jesteśmy jedna rozmowa” (Hölderlin) - w ,jedyności Ty, którym jest Bóg” (Ebner) - „nie wchodzę w stosunek z Bogiem, lecz z bliźnim” (Kierkegaard). Dlatego Wojtyła napisze: „I we mnie / coś zostaje z dziedzictwa i coś z zapowiedzi: / nurt mijania jest też nurtem wzbierania" (II 160).

W owych „nurtach mijania”, których jest „wiele”, „biegną wokół, tworzą pole” i których „nie wytrzymasz do końca”, ponieważ „pójdą dalej” (II 160), a więc w owej kipieli „mijania”, mieszczącej w sobie „dziedzictwo” (przeszłość) i „zapowiedź” (przyszłość), zajmuje nas śmierć i to, co po niej: „istniejesz stale ku śmierci, istniejąc ku przyszłości, / ona stale wstępuje w twój nurt" (II 161). Ja zwracając się do Ty, jest jednocześnie głosem wsłuchującym się w niepokój Ty. Jakim rozwiązaniem bytu jest śmierć? Ja pyta: „Czy wyzwoli cię z pól przemijania? / czy odbierze istnieniu całą przeszłość i przyszłość zarazem?" (II 161). Nie są to pytania skierowane do Ty. Są samozwrotne, a jednocześnie formułowane z pozycji tego, który wie, że bieg „ku” śmierci „nie jest już potrzebą ucieczki” (II 159), ale „pragnieniem odejścia ku Temu, w Kim istnienie znajduje całą swą przyszłość” (II 161). Tak oto „dojrzałość”, która jest „w miłości” i „bojaźń”, która jest „mądrością”, spotykają się wspólnie w „pragnieniu”, które dąży do spotkania z Bogiem. Śmierć albo „pragnienie odejścia”, jak ją nazwie synonimicznie Wojtyła, wpisane w porządek bycia ziemskiego („nurt mijania”) i porządek wieczności („,nurt wzbierania”), zostają włączone w mistyczną rzeczywistość przemienienia, nazwaną - taki jest tytuł tej części poematu - „mysterium paschale”, „tajemnicą Przejścia” (II 161). 


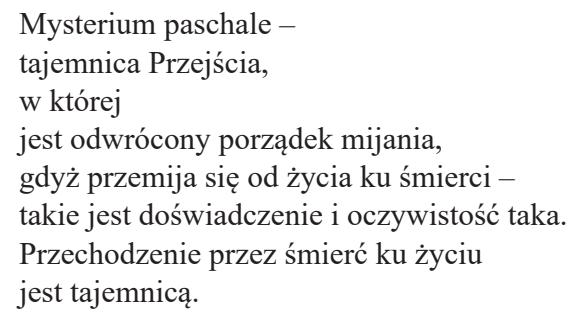

Ta sekwencja brzmi jak notatka poczyniona na użytek homilii. Nie jest poetycka, poetyckość jest dławiona przez zapiski na marginesie czegoś innego (może Biblii, a może jakiegoś filozoficznego traktatu), więcej nawet - zostaje zredukowana na rzecz banalności czy naiwności stwierdzenia: „Tajemnica - to zapis głęboki / dotychczas nie odczytany do końca” (II 161). Gdy przyjąć tezę Jana Okonia o homiletyczności poematów Wojtyły, powiedzielibyśmy, że właśnie tutaj - po raz pierwszy - dochodzi do głosu kapłan, który nie może zapomnieć o swojej roli „rycerza wiary”, by przywołać Kierkegaarda (Kierkegaard 85). Stąd owo notatkowe, wynikające z pragmatyki lektury i mowy publicznej „ułożenie” myśli. Poeta chce rozeznać się w prowadzonym „rozważaniu”, dlatego szkicuje myśli, które staną się dla niego odniesieniem w innych sekwencjach poematu.

Sekwencja trzecia Mysterium paschale znów jest poetycka, nawiązuje do sekwencji pierwszej, a jednak i ona wymyka się precyzyjnej organizacji wypowiedzi. Wersy nijak nie są do siebie podobne, wyłączają się z jakiegoś uprzedniego porządku, dziwią się sobie. Nie są segmentowane ani emocjonalnie, ani zwyczajowo, ani logicznie. Jakby poetyckość zmieszana z homiletycznością stawała się jakąś przeszkodą w określeniu relacji Ja i Ty, przy czym Ty jest już w ścisłym sensie tego słowa Bogiem. Początek sekwencji trzeciej jest identyczny jak pierwszej: „Nurtów mijania nie zatrzymasz. Jest ich wiele" (II 160, 161). Ale wnet perspektywa jednostkowa zmienia się w kosmiczną. Wymiary ulegają spotęgowaniu, metaforyka gęstnieje, zgodnie z przeświadczeniem, że „nurt mijania jest też nurtem wzbierania” (II 160).

Wciąż rośnie świat, pod każdą ludzką śmierć podchodząc wyżej wezbrany

każdym wejściem w orbitę myśli niepowtarzalnych atomów:

- napisze poeta (II 161-162). Zauważmy, że metafizyka ustępuje tutaj miejsca fizyce, uroda słowa gubi się w scjentystycznym dążeniu do ujęcia człowieka jako czegoś sprawdzalnego i przewidywalnego. Dlatego na koniec frazy mamy dwukropek,

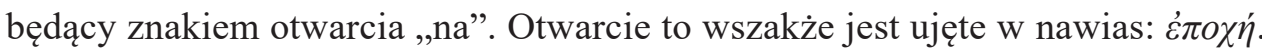
Epoché zaś nakazuje wstrzymać sąd na temat tego, co jest przedmiotem naszego „rozważania”, zawiesić nasze przekonanie o rozpoznaniu „tajemnicy”. Albowiem: „przemijając nadal ku śmierci, / trwamy w przestrzeni tajemnicy” (II 161). Czym 
jest ta transcendentalna redukcja, owo Husserlowskie „branie w nawias” (Waligóra 50-63)? Poeta wyraził to dosłownie, właśnie w strofie ujętej w nawias (II 162):

(gdy tętnem swego serca zapamiętywa się w nurtach mijającego stworzenia, umiera człowiek - wyższy niż świat wzbierający - upada poniżej wszystkiego, co dźwigał na sobie i wokół siebie jako „świat”, staje się mniejszy odejściem, zasypany w osnowie stworzenia znowu prochem niepowtarzalnych atomów, w których przemija nadal -

już nie ON,

ale Świat,

który rośnie na zgliszczach człowieka).

Zdumiewa ona ró w ni e ż swą niejasnością. Akcentuję słowo „,również”, ponieważ nieostrość sensów nakłada się tu na zmącenie stylu. Zamysł filozoficzny o tyle wymyka się podmiotowi mówiącemu, o ile on sam gubi się w nazywaniu tego, co wznosi się i upada, co już nie jest mijaniem człowieka, ale świata. Żeby wyjść z owej pułapki, która jest „wypisaniem” myśli z Biblii i filozofii, Wojtyła w czwartej sekwencji Mysterium paschale mówi o Nim. Nie wymieniony z imienia Jezus, który przeszedł całą drogę od narodzin po śmierć, staje się punktem zwrotnym w poemacie. Tajemnica Przejścia staje się odtąd Przejściem Chrystusa (Zarębianka 144-145).

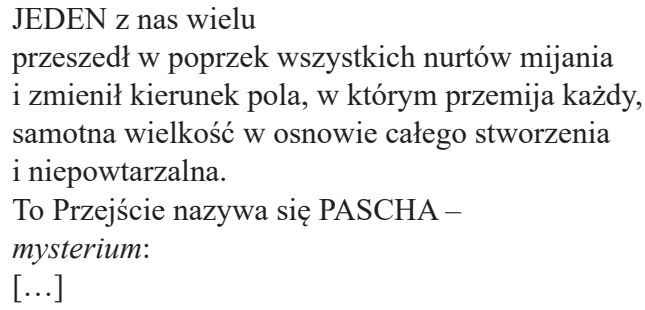

Po słowie „mysterium” poeta postawił dwukropek. Otworzył czytelnika na opowieść, którą zna z ewangelicznego przekazu². Ale Wojtyła nie chce opowiadać ewangelii, nie chce ewangelizować, jak to widzą krytycy. W sekwencji trzeciej czytaliśmy: „Wciąż rośnie świat, pod każdą ludzką śmierć podchodząc wyżej wezbrany” (II 161); „Świat, / który rośnie na zgliszczach człowieka” (II 162). Ale to „Świat” (napisany wielką literą) przemija, ,już nie ON” (pisany wielkimi literami). „ON”- człowiek

\footnotetext{
${ }^{2}$ Ks. Jan Machniak napisał: „Pascha Chrystusa jest punktem zwrotnym w całym procesie przemijania. Tę tajemnicę odkryli Apostołowie - Piotr i Jan - którzy biegli do grobu niedowierzając swoim oczom. Poeta widzi tu pewne podobieństwo do pasterzy, którzy poszli do Betlejem, by stwierdzić "przyjście« na świat Syna Bożego. Apostołowie z grobu szli doliną Cedronu, przez Ogród Oliwny na Górę, jakby przechodząc kolejne ogniwa Męki, która doprowadziła do Śmierci. Wszystkie te miejsca są dla poety świadkami prawdziwości »przejścia« Chrystusa. One pomagają człowiekowi odkryć w sobie duchowe miejsce dla jego własnego przejścia" (Machniak).
} 
- to „JEDEN z nas wielu”. O Nim więc będzie - powtórzmy - sekwencja czwarta, w której w wielkim skrócie zawarta zostanie kosmogonia narodzin i umierania: Jego (Jezusa), który będąc jednym z Nas (ludzi), pozwoli nam doświadczyć „Przejścia” (pisanego wielką literą), czyli „PASCHY” (pisanej wielkimi literami). Majuskułowość nie ma charakteru uwznioślającego. Jest wskazaniem na doniosłość „wydarzenia”, które w poezji - powiemy za Heideggerem - „rozporządza najwyższymi możliwościami człowieczeństwa" (Heidegger 190).

Wojtyła odwołał się tutaj do przypowieści alegorycznej, homiletycznie addytywnej przez sięgnięcie do słowa „biegli” (II 162):

\footnotetext{
biegli naprzód do groty, w której trzymano zwierzęta

jak w szopie - i podążali z daleka za gwiazdą,

biegli później do grobu, który okazał się pusty

i napełniony światłością,

a potem szli stromo w górę od potoku Cedron w dolinie,

pod urwiskami miasta, w których zadali Mu śmierć.
}

Bieg „ku” jest tu wyraźnie nacechowany: „biegli naprzód do groty”, „biegli później do grobu”. Bieg „ku” jest czym innym niż podążanie „w stronę”: „podążali z daleka za gwiazdą”, ,potem szli stromo w górę”. „Bieg” jest wypełniony emocją, „pragnieniem” spotkania; „dążenie” jest wypełnieniem misji, chęcią osiągnięcia celu. Tu i tam wszakże chodzi o spotkanie z „miejscem”, które „opiera się śmierci”, „przyjmuje zmartwychwstanie / jako najprostszą niewiedzę i pełnię wiary” (II 163).

4. W ten sposób poeta w części trzeciej, która nosi tytuł: Bojaźń, która leży u początku, powraca do części pierwszej poematu. Tam, jak pamiętamy, „bojaźń” została nazwana „początkiem mądrości”. Tutaj najpierw objawia się w próbie zrozumienia relacji początku i końca. „O jakże jesteś związane miejsce mojego mijania z miejscem narodzin...” - czytamy w apostrofie do „miejsca”, będącego punctum „obsuwania się" i „odsłaniania”, „zamykania” i „wschodzenia” (II 163). Miejsce to jest „ciałem” (bo „obsuwa się w śmierć”) i „ziemią” (bo „powierza się” jej „ciało”). Z tą podwójnością miejsca związana jest w sposób naturalny „bojaźń”, która pozornie jest zaprzeczeniem „mądrości”. Wykrzyknienie: „Ty, Boże! / Ty Jeden możesz ciała nasze odebrać ziemi z powrotem!" (II 163), czytane literalnie, jest bojaźnią umysłu lękającego się o swe ciało i jego „rozpad” w ziemi. Czytane jednakże przenośnie ujawnia pełnię zawierzenia Bogu (każdorazowo pisanemu majuskułą). Jest to zawierzenie niewolnicze, położenie nadziei w tym, że odwieczny porządek natury nie może być wymierzony przeciwko naturze samej, skoro jest właśnie jej porządkiem. Poeta obrazowo pokazuje to na przykładzie wschodu i zachodu słońca, nieprzypadkowo odwołując się do solarnej interpretacji boskości: „Ty wschodzisz nad nią [ziemią] powoli i zamysł Twój / nadal zrównywasz z powierzchnią każdego dnia 
/ oraz cieniem przechodniów w ulicach / popołudniową porą... w ulicach naszego miasta / pod zmierzch..." (II 163).

Ta część ma nierówne sekwencje. Zaczyna się wykrzyknieniem, a każda eksklamacja jest wyrazem zagubienia i lęku; potem w sekwencji drugiej głos zagubienia przemienia się w konstatację pewności, że „ostatnie słowo wiary” (czyli zwrot do Boga) zawsze „wychodzi naprzeciw / konieczności mijania” (II 164); w sekwencji trzeciej zaś poeta zwraca się w stronę „tajemnicy”, o której pisał w Mysterium paschale. Zapętlenia myśli, nawiązania do części wcześniejszych, przy jednoczesnej tendencji do redukcji liryki na rzecz mowy spekulatywnej, oddala poemat od poezji, a zbliża do meandrów traktatu. Podmiot mówiący wchodzi w rzeczywistość myśli tak dalece, że w granicach wiersza trzyma go jedynie wersyfikacja. Ale i tutaj, powtórzmy wcześniejszą naszą konstatację, nie odgrywa ona w wypowiedzi Wojtyły znaczącej roli. Nie jest znaczeniowo nacechowana, a sensy wynikające z inwersji czy innych zabiegów składniowych (np. ukrytego toku anaforycznego) są zaledwie retorycznym popisem mówcy.

Zmienność głosów albo - powiemy za Janem Błońskim - „czyjeś” głosy są tutaj zmiennością gatunków. Część trzecia jest genologicznym mixtum, połączeniem apelu, dogmatu i wezwania. W sposób wyrazistszy niż w części drugiej ujawnia swój religijny wymiar. O ile wcześniej ten wymiar poezji mogliśmy odczytywać przez aluzje, transpozycje cytatów biblijnych czy wręcz przypowieści, o tyle teraz zostaje on dopasowany ,ściśle” (znów przywołuję Błońskiego) do mowy teologicznej, by nie rzec, że do jej wierzchniego stroju: mowy obrzędowej. Widać to w modlitwie będącej trzecią sekwencją części Bojaźń, która leży u początku. Skoro „ostatnim słowem wiary” jest Bóg, a jest on zarówno „słowem, które odpowiada na zapis niesprzeczny z istnieniem” i jednocześnie „słowem najbardziej podejrzewanym” (II 164), to jest oczywiste, że podmiot mówiący w zwrocie do Boga stara się uchronić przed złem moralnym. Uchronić się zaś może tylko dzięki pogłębieniu swojej duchowości: ,pozwól działać we mnie tajemnicy, naucz działania / w duszy, która z ciała przejmuje swój lęk / i za nie się trwoży" (II 164). I dlatego - w modlitwie może objawić się „nadzieja, która sięga poza kres” (II 165).

5. Taki tytuł nosi czwarta część poematu Karola Wojtyły. Zwróćmy uwagę na konsekwencję medytacji poety, który w przestrzeni swojego utworu postawił cztery filary: „,dojrzałości”, „tajemnicy”, „bojaźni” i „,nadziei”. Są one zawsze w niegotowości. Dojrzałość jest dorastaniem do dojrzałości, tajemnica pragnieniem zrozumienia, bojaźń złączeniem lęków ciała i duszy, a nadzieja?

Nadzieja dźwiga się w porę ze wszystkich miejsc,

jakie poddane są śmierci -

nadzieja jest jej przeciwwagą,

w niej świat, który umiera, na nowo odsłania swe życie. 
Słowa o nadziei (II 165), choć wyrażone w poetyckiej definicji, intencjonalnie odsyłają do św. Pawła i jego Listu do Rzymian, gdzie otwarcie „ciała” na „duszę” jest jedynym źródłem odnowienia w zmartwychwstałym Chrystusie. „Obsuwając się w śmierć, odsłaniam oczekiwanie / i oczy utkwione w jedno miejsce / i w jedno zmartwychwstanie" - przeczytamy w części trzeciej Bojaźń, która leży u początku (II 163). „Św. Paweł stał się szczególnym wyrazicielem owego napięcia i zmagania, jakie nękają serce człowieka" - przeczytamy później w encyklice Dominum et vivificantem (DV 55). Tak to zostało wytłumaczone przez Papieża, który najpierw zmierzył się z tym problemem jako poeta:

W wypowiedziach Pawłowych nakładają się na siebie - i wzajemnie przenikają - wymiar ontologiczny (ciało i duch), etyczny (dobro i zło moralne) oraz pneumatologiczny (działanie Ducha Świętego: dar łaski). Słowa jego (zwłaszcza z Listu do Rzymian i do Galatów) pozwalają nam poznać i żywo odczuć wielkość owego napięcia oraz walki, jaka toczy się w człowieku pomiędzy otwarciem wobec działania Ducha Świętego a oporem i sprzeciwem względem Niego, względem Jego zbawczego daru. (DV 55)

Antynomia „ciała” i „ducha”, mówi Papież za św. Pawłem, to „napięcie” i „walka” między „otwarciem” a „oporem i sprzeciwem”. I dalej:

Te przeciwstawne czynniki czy bieguny to od strony człowieka jego ograniczoność i grzeszność - newralgiczne punkty jego rzeczywistości psychologicznej i etycznej, a od strony Boga - tajemnica Daru: owo nieustanne udzielanie się życia Bożego w Duchu Świętym. Kto zwycięży? Ten, kto potrafi przyjąć Dar. (DV 55)

W ustach poety ta sama świadomość zostanie wyrażona w słowach (II 165):

W przestrzeni tej, w najpełniejszym świata wymiarze,

JESTEŚ

i wtedy ja mam sens i moje w grób opadanie

i przechodzenie w śmierć -

a rozpad, który mnie czyni prochem niepowtarzalnych atomów,

jest cząstką Twojej Paschy.

Odnowienie w zmartwychwstałym Chrystusie, który Jest, to „nadzieja, która sięga po kres” (II 165), a choć jej nie potwierdza ,żadne złoże własnej tylko pamięci”, i choć „Śmierć jest jednak doświadczeniem kresu / i ma w sobie coś z unicestwienia”, to jednak „nadzieją odrywam moje »ja«, muszę oderwać, aby stanąć nad unicestwieniem..." (II 166). Wojtyła mówi tu o zawierzeniu swojego losu temu losowi, który doświadczył Przejścia. Jest to zawierzenie pełne, bo „nadziei w zwierciadle mijania nie odtwarza nic"; nic - „tylko Twoje Przejście paschalne / zespolone z zapisem najgłębszym mego bytu" (II 166). Odnosi się wrażenie, że poezja liryczna nie byłaby zdolna unieść ciężaru tego wyznania, że - prawdopodobnie - żadna poezja, 
która zagłębia się w językowe otchłanie znaczeń, nie potrafiłaby oddać tego, co jest „otwarciem” wobec „oporu i sprzeciwu”. Zawierzenie odnowieniu w Chrystusie zmartwychwstałym staje się właściwym wymiarem nadziei (II 166-167):

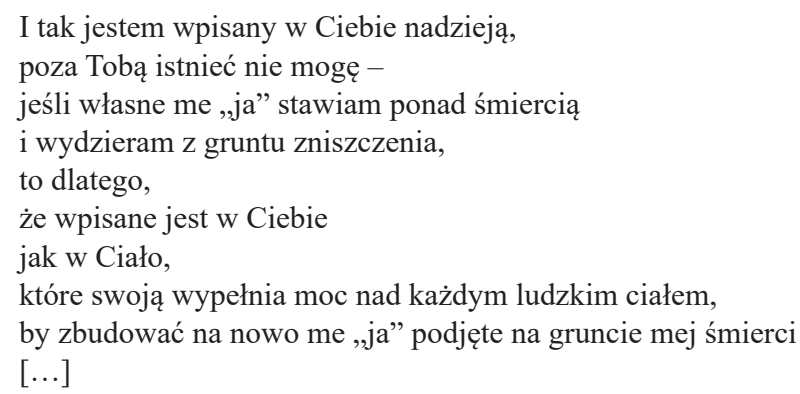

6. Śmierć jest ,nagłym Wichrem, / którego nie udźwignie żaden na ziemi człowiek”; „Ten wicher pchnięty Twoją dłonią staje się Milczeniem”. Ziemia - ,prastara gleba / świata, którego dotykam moją śmiercią / i ostatecznie przeszczepiam w siebie" - wiąże Ja z „Twą Paschą - czyli PRZEJŚCIEM” (II 167). Tymi słowami poeta stara się myślowo ująć pneumonologiczną, przywołaną już wcześniej w słowach Ebnera, relację Ja, którego ziemskie bycie byłoby puste bez dojrzewającej w nim nadziei na wieczność, z boskim Ty, „w którym ciało mej duszy i dusza ciała zespala się na nowo, / by swój byt - dotąd oparty o ziemię - ostatecznie oprzeć o Słowo" (II 167). Myślowo, to znaczy tak, jak to wyraził ściśle w medytacji Odkupienie szuka twego ksztattu, by wejść w niepokój wszystkich ludzi: „przez myśl wchodzę sam w siebie / i stale od siebie odchodzę, / jestem także w pośrodku wszystkiego, / tak jak ona jest w pośrodku mnie" (II 171). Rozumiemy więc, z jakiego powodu nazywamy Rozmyślanie o śmierci poematem filozoficzno-religijnym, albo medytacją, która przybrała kształt poematu.

Medytacja jest, czytamy w słowniku, ,zagłębianiem się w myślach, rozmyślaniem, rozpamiętywaniem, dumaniem; namyślaniem się, rozważaniem” („Medytacja"). W dojrzałej medytacji filozoficzno-religijnej, a więc takiej, która nie poświęca myśli na rzecz zachwytu, namysł ten zawsze musi spotykać się z przeciwstawnymi sobie siłami, czyli - jak czytamy w Dominum et vivificantem - oporem „ciała” wobec zbawczego daru „ducha”, a jednocześnie z otwarciem na jego „działanie” (DV 55). „W poezji tak religijnej jak ta mało jest zwrotów, obrazów lub fraz, które bezpośrednio nazywają po imieniu Boga, sprawy święte" - pisał Marek Skwarnicki. I dodawał: ,jej tematem jest rzeczywistość ludzka" (Skwarnicki 9). A my to rozumiemy, wszak poeta wyznawał w Pieśni o Bogu ukrytym: ,jesteś samą Ciszą, wielkim Milczeniem" (II 329). 
7. Nie odrzucając tezy o myślowym, medytacyjnym charakterze poematów autora Kamieniołomu, przeciwnie: podnosząc jej znaczenie do wymiaru pewnika, Jan Błoński podkreślał jednak że „poezja Karola Wojtyły jest poezją ściśle religijną” (Błoński 149). Zapytajmy, czy religia potrafi dogłębniej ująć naturę w nieskończoności niż racjonalne działanie człowieka w jego ograniczonej przestrzeni? Zapytajmy nie Wojtyłę, ale kogo innego - Piotra Czaadajewa. Twierdził on, że „w ograniczonej przestrzeni” słowo jest „gestem”, czyli „głosem skutecznym”, natomiast „W nieskończoności natury” jest „Słowem doskonałym”, czyli „słowem tworzącym” (Czaadajew 22, frag. 25). W pierwszym wypadku piszemy je małą, w drugim wielką literą. Granica między doczesnym a wiecznym nie biegnie jednakże przez gramatykę (wielkość liter), fizykę (głośność) czy nauki społeczne (sprawczość), ale przez ideę, która łączy byt wszystkich czasów w związku „stałym, koniecznym i absolutnym” (frag. 27). Czaadajew pyta: „Czym byłby świat, gdyby nie przyszedł Jezus Chrystus?”. I odpowiada: „Niczym” (frag. 65). Tajemnica przyj ś c i a jest tu tajemnicą pr zej ś ci a. „Czym jest chrześcijaństwo? Nauką życia i śmierci” (frag. 61).

Wyrastając z ewangelicznego przeżycia, myśli Czaadajewa bliskie są także ewangelicznemu przeżyciu Wojtyły. Jego „poezja ściśle religijna” wyraża się w bezustannym mierzeniu się z zmaganiami „ducha” i „ciała”, czyli także - jak w Rozważaniu o śmierci - „życia” i „śmierci”. Błoński ten rodzaj poetyckich zmagań nazwał „nawróceniem”. „Poeta nawrócenia stara się więc złączyć - poza granicami języka - trud wysiłku i dar łaski”. Poezja zaś „,skupiona na jednej tylko sprawie, na jednym momencie - momencie nawrócenia - zdaje się jedynym środkiem, który pozwala uczynić uchwytnym, przekazywalnym misterium przejścia, narodziny wiary" (Błoński 155).

\section{BIBLIOGRAFIA}

Błoński, Jan. „Poezja nawrócenia”. Pisarstwo Karola Wojtyty - Jana Pawła II w oczach krytyków i uczonych, oprac. Krzysztof Dybciak, PIW, 2019, ss. 147-155.

Czaadajew, Piotr. „Fragmenty i różne myśli”. Przeł. Marian Kisiel, Śląsk, nr 10, 2019, fragment 25 , $26,27$.

DV 55=Ioannes Paulus pp. II. Dominum et vivificantem, www.vatican.va/content/john-paul-ii/p1/encyclicals/documents/hf_jp-ii_enc_18051986_dominum-et-vivificantem.html. Dostęp: 30.03.2020.

Ebner, Ferdinand. „Fragmenty pneumatologiczne”. Przeł. Jan Doktór. Teksty filozoficzne. Twarz Innego, red. Bogdan Baran, PAT, 1985, ss. 29-46.

Gruda, Stanisław Andrzej [K. Wojtyła]. „Rozważanie o śmierci”. Znak, nr 3, 1975, ss. 271-276. Przedruk: Wojtyła, Karol - Jan Paweł II. Dzieła literackie i teatralne, t. 2: Utwory poetyckie (19462003), red. Zofia Zarębianka, Znak, 2020, ss. 159-167.

Heidegger, Martin. „Hölderlin i istota poezji”. Przeł. K. Michalski. Teoria badań literackich za granica. Antologia, t. 2, cz. 2, wybór, rozprawa wstępna, komentarze Stefania Skwarczyńska, Wydawnictwo Literackie, Kraków 1981, s. 191. 
Juros, Helmut. „Bojaźń”. Encyklopedia katolicka, red. Feliks Gryglewicz, Romuald Łukaszyk, Zygmunt Sułowski, t. 2, TN KUL, 1985, kol. 740.

Kierkegaard, Søren Aabye. Bojaźń i drżenie. Choroba na śmierć. Przeł. i wstępem opatrzył Jarosław Iwaszkiewicz, PWN, 1972, ss. 294.

Machniak, Jan. „Bóg i człowiek w poezjach Karola Wojtyły — Jana Pawła II”, www.janmachniak. pl/index.php/moje-wyklady-2/52-bog-i-czowiek-w-poezjach-karola-wojtyy-jana-pawa-ii-cz-iv. Dostęp 11.02.2020.

„Medytacja”. Słownik języka polskiego, red. Witold Doroszewski, t. 4, Wiedza Powszechna, 1964.

Okoń, Jan. „Życiowy profil poety (o drodze twórczej Karola Wojtyły)”. Pisarstwo Karola Wojtyty Jana Pawła II w oczach krytyków i uczonych, oprac. Krzysztof Dybciak, PIW, 2019, ss. 86-110.

Skwarnicki, Marek. „Słowo wstępne”. Karol Wojtyła. Poezje i dramaty, Znak, 1979, ss. 5-10.

Stachowiak, Lech. „Bojaźń Boża”. Encyklopedia katolicka, red. Feliks Gryglewicz, Romuald Łukaszyk, Zygmunt Sułowski, t. 2, TN KUL, 1985, kol. 741.

Waligóra, Marcin. Wstęp do fenomenologii, Universitas, 2013, ss. 50-63.

Wojtyła, Karol - Jan Paweł II. Dzieła literackie i teatralne, t. 1: Juwenilia (1938-1946), red. Jacek Popiel i in., Znak, 2019.

Wojtyła, Karol - Jan Paweł II. „Rozważanie o śmierci”. Dzieła literackie i teatralne, t. 2: Utwory poetyckie (1946-2003), red. Zofia Zarębianka, Znak, 2020, ss. 159-167.

Zarębianka, Zofia. „Śmierć jako spełnienie (w) miłości. Dialektyka śmierci i miłości w Rozważaniu o śmierci Karola Wojtyły". Zofia Zarębianka. Spotkanie w Stowie. O twórczości literackiej Karola Wojtyły, Wydawnictwo Pasaże, 2018, ss. 139-150.

\section{POEMAT O ŚMIERCI. \\ ROZWAŻANIE O ŚMIERCI KAROLA WOJTYŁY JAKO MEDYTACJA FILOZOFICZNO-RELIGIJNA}

\section{Streszczenie}

W artykule podjęto próbę interpretacji Rozważania o śmierci Karola Wojtyły jako poematu filozoficzno-religijnego. W utworze zatarte zostały odwołania do literatury pięknej, poeta polemicznie przywołał metafizykę egzystencjalną (Heidegger) i aprobatywnie Ewangelię (listy św. Pawła) jako źródło swojej medytacji. Prowadząc rozważania wokół pojęć „dojrzałości”, „tajemnicy”, „bojaźni” i ,nadziei”, Wojtyła widzi śmierć jako gotowość do „trudnego spotkania” z „Tym, w Kim istnienie znajduje całą swą przyszłość”. Medytacja jest spotkaniem Ja, czyli osoby, wobec której Ty, czyli Bóg, ustawia się na pozycji możliwego dialogu. Jest to relacja określana przez filozofów dialogu jako „możliwość bycia zagadniętym”. Mówiąc o antynomii „,ciała” i „duszy”, poeta przeczuwa, że wpisane jest w nią również przeciwstawienie ,życia” i ,śmierci”. Wykładnię tę potwierdzi po latach, jako papież, w encyklice Dominum et vivificantem.

Słowa kluczowe: Karol Wojtyła; Rozważanie o śmierci; poemat; medytacja; religia 


\section{A POEM ON DEATH \\ KAROL WOJTYŁA'S ROZWAŻANIE O ŚMIERCI AS PHILOSOPHICAL AND RELIGIOUS MEDITATION}

\section{Sum mary}

This article focuses on Karol Wojtyła's Rozważanie o śmierci [“On Death”] as a philosophical and religious poem. Wojtyła's text includes numerous references to other literary works; as sources of his meditation, the poet polemically recalls existential metaphysics (Heidegger) and affirmatively turns to the Gospels (the letters of St. Paul). Having discussed such notions as "maturity," "mystery," "angst," and "hope," Wojtyła perceives death as the readiness for the "difficult encounter" with "the One in whom one's being embraces its entire future." In fact, the meditation itself is the encounter: God - that is, you - makes dialogue possible here, as He posits himself towards the person, that is, $I$. The philosophers of dialogue know this relationship as "the possibility of being addressed." Recognising the antinomy of "body" and "soul", the poet presumes that the contrast of "life" and "death" is inscribed in it as well. As Pontiff, Wojtyła confirms this intuition in Dominum et Vivificantem.

Keywords: Karol Wojtyła; Rozważanie o śmierci; poem; meditation; religion 